\title{
A Better Method for Analyzing the Costs and Benefits of Fundraising at Universities Patrick Michael Rooney
}

This article develops a new methodology for a more comprehensive and useful analysis of the costs and benefits of fundraising, as well as the total costs and net benefits associated with development efforts in general. This approach does a better job of linking the timing of return of fundraising efforts and measuring the actual return on investments in fundraising (as opposed to the reported return) than the widely used guidelines from the Council for Advancement and Support of Education and the National Association of College and University Business Officers (CASE/NACUBO) (1990). The implications are a better methodology for practitioners that they can use to enhance internal decision making and a better methodology for boards to use in evaluating performance and accountability. Recently, other large, public universities have begun using several of these concepts in the assessment of their development offices (Rooney, 1998).

\begin{abstract}
Doing this work [monitoring costs and benefits] is necessary and required; disclosing the results is laudable and brave. Take courage pills; the results will be praiseworthy and more than worth the effort.
\end{abstract}

-James Greenfield, 1996 (p.xv)

Note: An earlier draft of this article was presented at the 26th Annual ARNOVA Conference, Indianapolis, in December 1997. The author would like to thank the following for their comments and suggestions throughout this endeavor: Gerald Bepko, chancellor, Indiana University Purdue University (IUPU)_Indianapolis; Joyce Claflin, senior vice president for finance and administration at the Indiana University Foundation (IUF); Linda Griffin, director of administration, Indiana University (IU) School of Medicine; Phil Hardwick, vice president, IUF, Indianapolis; Curt Simic, president, IUF; David Smith, associate dean for development, IU School of Medicine; Rich Steinberg, professor of economics; Lynne Sullivan, director, university relations, IUPU-Columbus; and 
$\mathrm{T}$ HIS article proposes a new methodology for evaluating the efficacy and efficiency of fundraising efforts at universities. It does so by trying to include all of the relevant costs and benefits and to exclude those that are largely irrelevant-despite the historical precedent for including them. Moreover, it tries to more closely link the time periods of development expenditures and receipt of private gifts. If followed, this approach will add a level of relevance that will enable decision makers to more accurately track both the actual benefits of development efforts and the concomitant costs. As a result, university administrators should be better able to determine whether or not those efforts should be expanded or curtailed and whether or not the efforts are more or less costly than those of their peers.

For example, by more accurately measuring the costs and benefits of development efforts, university administrators will have a much better understanding of the true net benefits accruing from various fundraising strategies and from the development effort overall. This will facilitate the decision as to whether or not to pursue a given strategy and will provide a better estimate of the gross revenues necessary in order to achieve the goals of a fundraising effort. In addition, the administration will be able to compare the results of the development office with other peer or benchmark programs and more accurately gauge the effectiveness of the development program with respect to fundraising than it is currently able to with the standard protocols delineated in CASE/NACUBO (1990). This new methodology will still allow for direct comparisons with other universities that use the CASE/NACUBO guidelines and with other fundraising organizations' development efforts.

Warren Heeman (1979) and other scholars argue that there is a distinction between fundraising efficiency (for example, minimizing the average cost per dollar raised) and effectiveness (for example, maximizing the net between total gifts less total fundraising costs). Heeman illustrates his point with an example. Most would prefer a program that raised $\$ 3$ million and spent $\$ 300,000$ (cost of fundraising equals 10 percent) over a program that raised $\$ 2$ million and spent only $\$ 160,000$ (8 percent cost of fundraising). The former would have increased the net resources available for mission enhancement by $\$ 860,000$ more than the latter campaign-despite the higher cost-benefit ratio of the larger campaign.

Richard Steinberg (1994) defines the economic concept of optimal fundraising efforts as the level of expenditure such that marginal

Gene Tempel, executive director, IU Center on Philanthropy. In addition, three anonymous referees made several excellent suggestions. Of course, the author is solely responsible for any remaining errors or omissions. The views expressed herein are those of the author and do not necessarily reflect those of any of the individuals who made comments on the article, IU, IUPU-Indianapolis, or the IUF. 
costs equal marginal benefits. In other words, the development program should continue to invest more resources into fundraising efforts up to the point where it costs one dollar to raise one dollar. This approach will yield the maximum total net resources available to the organization. Steinberg also discusses other maximizing strategies (for example, budget maximizers and service maximizers, subject to "acceptable" fundraising techniques) but goes on to say, "[cost-benefit] ratios do not matter" (p. 14). When evaluating a development program, the average cost per dollar received (or costbenefit ratio), rather than the marginal costs, remains an important evaluative tool because the marginal costs and the marginal benefits are much more difficult to identify or to compare with other fundraising efforts.

Furthermore, many donors and board members continue to be concerned about accountability and best practices and are likely to continue to compare the performance of the targeted development program with other such efforts. Although it is not simply the case that large costs of fundraising are inherently bad or "too high," the costs and benefits need to be evaluated in the proper context. For example, as will be discussed later in more detail, Greenfield (1996) argues that benchmarking should be done for each type of fundraising activity rather than a simple examination of total costs and total benefits produced by the development office. Perhaps equally important, it is necessary to evaluate the costs and benefits of the development program in its context. That is, a high cost of fundraising may be quite acceptable for newer, less developed, public universities but might be unacceptable for a long-standing private university that has had a long history of donor relations and development success. Other distinctions arise within colleges and universities and many more would arise in comparisons among all organizations that engage in fundraising.

Rooney (1999) discusses whether or not the distinction between fundraising effectiveness and efficiency is real. Rooney demonstrates that under most plausible circumstances, a fundraising effort that maximizes net revenue will operate at the point that is both efficient and effective as defined by Heeman. In exceptional cases, these operating points may not coincide, but they are not necessarily different.

\section{Private Grants}

CASE/NACUBO (1990) recommends that universities include private (that is, nongovernmental) grants as a part of the benefits portion of the cost-benefit analysis. For some campuses this issue may be rather insignificant, but for many universities private grants may be nearly equal to, or even greater than, the amount of private gifts. For example, in the case study discussed in this article, private grants are nearly three times as great as private gifts. The justification for inclusion of the private grants is that they are part of the
Although it is not
simply the case
that large costs
of fundraising
are inherently
bad or "too
high," the costs
and benefits need
to be evaluated
in the proper
context 


The cost, or
opportunity cost,
of university
leaders' time
should be
incorporated into
the cost-benefit
analysis

total voluntary support generated by the university. In some cases, the development office may participate in securing some of the private grants for the university. In these cases, it may be appropriate to include those private grants that the development office helped to attract as a benefit in the cost-benefit analyses-as long as the concomitant costs are also included.

However, from a campus decision-making perspective, private grants are largely irrelevant to analyzing the costs and benefits of fundraising for three main reasons. First, the grants are usually the results of efforts by faculty and staff to obtain externally funded research awards that have nothing to do with fundraising.

Second, there is no estimation in costs of fundraising studies of the value of the time of faculty and staff in attracting, maintaining, and (hopefully) renewing these grants. There is also no estimation of the costs expended by the campus for the administration of these grants. Even when universities have a good estimate of some portion of the costs of securing these private grants (such as the costs of a research and sponsored programs office), these costs are not included in the cost side of the cost-benefit ratios commonly used by development offices that follow CASE/NACUBO (1990). Robert Teitelbaum (1979) suggests that accurate studies of fundraising costs should include the costs of obtaining and administering these grants but should exclude expenditures to implement the grants.

Third, if development offices want to include private grants as part of their benefits, it would be both more useful from a management decision-making perspective and more intellectually honest to include them in a distinct cost-benefit analysis. This analysis would allocate the pro rata time (compensation), the direct expenditures of the development office devoted to these activities, and the pro rata share of the development office's indirect costs for these activities, comparing these costs directly with the private grants received through the development office's efforts. Wesley Lindahl (1994) agrees that research grants that are solicited directly, without assistance from the development office, as well as other "low development effort gifts," should be excluded from the benefits component when conducting fundraising cost-benefit analyses.

\section{Time of the President and Deans}

According to the CASE/NACUBO guidelines (1990), the development efforts measured in this article do not include the pro rata share of the compensation of the president, the chancellor, or any of the academic deans devoted to development. However, the cost, or opportunity cost, of university leaders' time should be incorporated into the cost-benefit analysis. While this cost would be difficult to measure precisely, the pro rata share of compensation for the time that academic leaders spend on fundraising would be a useful yardstick for measuring the opportunity cost of their time. Given the detailed scheduling of these senior academic managers' time, it would 
be quite possible to calculate an approximate percentage of their time devoted to fundraising and related activities.

Frequently, it is the personal relationships of, and time devoted by, the key leaders in the university that actualize potential gifts, especially in the case of large gifts. The modern dean and president spend a great deal of time (some would say an inordinate amount) engaged in fundraising activities. If, however, the academic leaders of the university did not need new resources to implement the mission of the university, presumably, their time could be better spent on other activities. While fundraising has become an important ingredient in the success of most universities and the perceived success of their presidents, it is important (or at least should be) only to the extent that it improves the net resource base for mission fulfillment. It should not be viewed as an end in itself.

\section{Costs for Alumni, Public, and Constituent Relations}

CASE/NACUBO (1990) also suggests that costs of fundraising should not include the costs for alumni relations, public relations, or any other constituent relations. They suggest that those costs are "considered as expenditures in support of fund-raising, rather than as fund-raising costs" (p. 15). This may, in fact, be a way of obscuring costs. For example, a development program could shift many of its personnel and nonpersonnel expenditures to these other areas and, thereby, artificially lower its cost-benefit ratio. Even if not done intentionally to mislead, it should be clear that, holding everything else constant, larger expenditures for alumni or public relations are likely to be associated with larger gifts.

John Leslie (1979) points out that the quality of inputs affects the fundraising outcomes, as does the quantity of inputs, such as expenditures for institutional advancement, including public relations, alumni relations, and development. Perhaps it would be better and more relevant to publish another set of ratios in order to display the costs of fundraising both with and without these additional expenditures in support of fundraising. Although it would be unfair to include all of the costs associated with alumni relations, public relations, or any other constituent relations as true costs of fundraising (because these offices also provide other services), it might be useful to illustrate these costs in order to convey the total effort devoted to institutional advancement and donor cultivation.

\section{Asset Management and Administrative Costs of the Development Office}

Another important methodological change is to include the asset management and administrative costs associated with a development office. There would not be significant administrative and asset management costs in a development program if there were not fundraising 


\begin{tabular}{c}
\hline Another \\
important \\
methodological \\
change is to \\
include the asset \\
management and \\
administrative \\
costs associated \\
with a \\
development \\
office
\end{tabular}

costs and efforts. (However, even absent any fundraising efforts, there may be voluntary gifts that would necessitate some administrative and asset management costs.) Although these are not true fundraising costs, they are costs derived from fundraising efforts that are not of direct benefit to mission fulfillment.

For those reluctant to consider these costs as relevant to fundraising, it must be emphasized that a campus engages in fundraising activities in order to generate additional, or "net new," resources to facilitate the campus's ability to accomplish its mission. When evaluating the costs and benefits of fundraising, one should look at all of the costs associated with fundraising that absorb resources, which are then not available to the campus for mission enhancement. The "full costs" of development offices, therefore, include not only the costs of fundraising per se, but also the costs incurred by the campus to pay its share of the development program's administrative and asset management costs. Perhaps the analysis could be better understood in the following depiction:

Net new resources available for mission enhancement $=$ GIFTS - COSTS

where

$$
\begin{aligned}
\text { GIFTS }= & \text { Private gifts } \\
\text { COSTS }= & \text { Fundraising costs }+ \text { Asset management costs } \\
& + \text { Endowment administration } \\
& + \text { Costs in support of fundraising }
\end{aligned}
$$

This may be a stringent standard, but if we are unwilling to have honest and meaningful standards, then we must ask whom we are trying to fool and why.

It could be argued that the costs that are not directly related to fundraising (for example, asset management, endowment administration, and other costs "in support of fundraising") should be evaluated in distinct but parallel analyses that cover the full costs (and benefits) associated with development programs. For example, there may be separate cost-benefit ratios that are specific to fundraising, asset management, endowment administration, and private grants. It might be best to display these costs as a percentage of annual private gifts, as a percentage of the total endowment, or both, or by other measures yet to be determined.

\section{Space Utilization, Depreciation, Maintenance, Utilities, and Similar Costs}

It must be acknowledged that the use of "full costs" in the results section of this article is somewhat of a misnomer as it does not include any campus fees for space utilization, depreciation, maintenance, utilities, and so on, in the development offices that are 
distributed throughout the various units on campus. This may be a shortcoming, but the campus has not developed a well-defined model for accurately tracking these costs at the unit level (in the School of Science, for example)—much less a subunit level (such as in a shared office for development and alumni relations). (The results section does include these costs for the main development office as part of the administrative costs.) Excluding these costs is the standard approach per CASE/NACUBO (1990). Teitelbaum (1979), however, argues that such costs should be included or at least approximated by using an average rental rate for office space in the area. Similarly, Greenfield (1996) argues that the overhead costs allocated across the fundraising benefits ought to include administrative work, personnel supervision, office equipment, utilities, and depreciation.

\section{Changes in Pledges and Changes in Bequest Expectancies}

In order to do a better job of linking the time when development effort expenditures are made and the time when the benefits of the resulting gifts are counted, it is necessary to modify the methodological approach to incorporate changes in pledges and changes in bequest expectancies. Ignoring these changes overstates the costs incurred in a given year and understates the benefits resulting from those costs in a given year. Although the net effect is probably averaged out in a year-to-year comparison (especially if one uses a threeor five-year moving average) of institutional data for pledges (but not necessarily for bequest expectancies), making these modifications makes good accounting and economic sense. Bequests are more complicated because of the very long time frames involved in cultivating them. Large bequests further complicate cost-benefit analyses because such bequests can significantly influence cost-benefit measures in any given year-even if they are averaged in a three- or five-year moving average. Of course, if there is a steady stream of large bequests coming to fruition each year, there will not be much amplitude in the gift cycle.

It should be clear that one wants to use changes in pledges and expectancies so as to avoid double-counting the pledges and expectancies. By focusing on changes rather than on the level of pledges and expectancies, one nets out the movement from promises to actual gifts. Furthermore, and perhaps most important, the Financial Accounting Standards Board (FASB) has mandated that nonprofit organizations show these on their books beginning with any fiscal year after December 15, 1994. According to FASB, "organizations are required to report as revenue in their financial statements all unconditional promises to give." An "unconditional promise" is characterized as an "irretractable commitment" (CASE, 1996, pp. 75-76). It should be noted that these regulations may change as FASB and the
By focusing on changes rather than on the level of pledges and expectancies, one nets out the movement from promises to actual gifts 
Government Accounting Standards Board (GASB) try to reconcile language differences but still account for pledges to universities and university-related foundations.

Although not established in the original CASE/NACUBO guidelines (1990) as a protocol, there is some evidence (CASE, 1996; Lindahl, 1994) that using changes in pledges and changes in bequest expectancies may become the norm. Also, a group of university financial officers (primarily from the Big Ten, Big Twelve, and Pac Ten) have been meeting to try to develop a more meaningful standard. They have proposed illustrating the data both with and without grant income and with and without changes in pledges and changes in bequest expectancies. To facilitate the discussion, changes in bequest expectancies are shown at both their present values and face (future) values. (See Rooney, 1998, for a more complete discussion and comparison of these results.)

\section{Cost-Benefit Ratios by Type of Fundraising Activity}

Greenfield (1996) reports costs of fundraising averages for many different types of nonprofits and for many different types of fundraising. His research synopsis is that "professional fund-raising executives suggest that a mature fund development program should be able to achieve a bottom-line cost-benefit ratio of $\$ 0.20$ to $\$ 0.30$ to raise $\$ 1.00$ after three years of operation" (p. xxx). However, the range is much wider between types of fundraising activities. For example, acquisition of new patrons by direct mail may cost as much as $\$ 1.25$ to $\$ 1.50$ per dollar raised whereas getting the same patron to renew averages between $\$ 0.20$ and $\$ 0.25$ per dollar raised. According to Greenfield, fundraising costs for capital campaigns range between $\$ 0.10$ and $\$ 0.20$, and foundations average $\$ 0.20$, per dollar raised. Ideally, there would be a separate cost-benefit analysis for each type of fundraising, which would create the environment for more meaningful benchmarking in each segment of a given development program.

\section{The Campus Study}

The data used in this article are the result of a multiyear attempt to analyze the costs and benefits of fundraising efforts at a large, Midwestern, urban, public, research university. The costs of fundraising at this campus are supported by four main sources. First, the campus is assessed a development services fee by the development office, 100 percent of which is applied to covering fundraising costs. Second, the development office collects an investment management fee based on relative shares of each school's assets held by the development office in various forms of investments. Part of this fee pays for fundraising costs, and part of it pays for administrative and asset management costs. Third, the development office charges campus units a 
user fee for telemarketing services. Fourth, individual deans (or directors) may have their own development efforts, for which they fund the direct and indirect expenses from resources within that unit.

Two of the goals of the campus study were to obtain the most recent estimates for the costs and benefits of fundraising and to track the historical data. This second goal was intended to measure whether or not there were trends in the costs or benefits that needed to be addressed or at least recognized. Another goal was to establish benchmark data with which future results could be compared. Both of these goals required gathering as much historical data as possible and estimating those data that were necessary but no longer (if ever) available directly. This study reports the data from a decade of changes (1984 through 1994-95), with special emphasis on the 1994-95 fiscal year, which is the most recent year for which complete data are available. To allow for better historical comparability, all dollar figures are converted to real (inflation-adjusted) 1993 dollars; that is, all dollars are expressed as if they were equal to the purchasing power of a dollar in 1993.

\section{Gift Data}

The gift data are the best and most complete data available. The gift data in Table 1 indicate some variability that is somewhat idiosyncratic to school, campus, and university-wide capital campaigns. (Note that the data for 1984-1990 are expressed in calendar years, and the remainder are expressed in fiscal years. This is unavoidable because the gift data are not available in a consistent format.)

\section{Cost Data}

Analyzing the costs of fundraising is more difficult for numerous reasons. First, the development office did not have the systems to capture campus-specific data for all of its assessments for the entire

Table 1. Private Gifts

\begin{tabular}{lrrrr}
\hline & \multicolumn{2}{c}{ Nominal \$ } & \multicolumn{2}{c}{ Real 1993 \$ } \\
\cline { 2 - 3 } \cline { 5 - 5 } Year & Millions & $\begin{array}{c}\text { Percentage } \\
\text { Change }\end{array}$ & Millions & $\begin{array}{c}\text { Percentage } \\
\text { Change }\end{array}$ \\
\hline 1984 & 3.9 & & 5.4 & \\
1985 & 6.7 & 72 & 9.0 & 66 \\
1986 & 10.0 & 49 & 13.2 & 47 \\
1987 & 8.9 & -12 & 11.3 & -15 \\
1988 & 16.0 & 81 & 19.5 & 74 \\
1989 & 9.6 & -10 & 11.2 & -43 \\
1990 & 9.5 & -1 & 10.5 & -6 \\
$1991-92$ & 10.0 & 5 & 10.6 & 1 \\
$1992-93$ & 10.8 & 8 & 11.2 & 5 \\
$1993-94$ & 12.3 & 14 & 12.3 & 10 \\
$1994-95$ & 14.2 & 15 & 13.8 & 12 \\
\hline
\end{tabular}

Two of the goals of the campus study were to obtain the most recent estimates for the costs and benefits of fundraising and to track the historical data 
period. This made it necessary to estimate the investment management fee for most of the years. Second, the development office did not keep historical records of its distinct costs for development activities, administrative activities, and asset management activities prior to the fiscal year 1990-91. Hence, these data do not extend back to the entire period included in this study. Third, this study was complicated by the fact that these records were not broken down by campus until the fiscal year 1994-95. Finally, given that the campus is part of a large, multicampus, statewide system, it should be acknowledged that costs paid by the campus to the university-wide development office are not necessarily equal to the fundraising-related expenditures made by the development office on the campus's behalf. However, it is reasonable and simplifying to assume that those costs do equal the development office's expenditures on the campus's behalf, and this article uses that assumption.

\section{Fundraising, Asset Management, and Administration Costs}

To simplify the presentation, cost estimates are disaggregated into the following: fees and assessments related to fundraising paid to the development office; fees and assessments not directly related to fundraising (for example, asset management and administration of the endowment) but paid to the development office; and development expenditures made by the academic units (see Table 2). The first column lists the total user fees and campuswide assessments paid by the campus to the development office directly for fundraising activities. The second column lists the fees and assessments paid by the campus to the development office for asset management and administrative expenditures such as endowment administration. The third column is the sum of the first two columns. The fourth column

Table 2. Expenditures for Fundraising and Asset Management/Administration in Nominal Dollars

\begin{tabular}{lcccc}
\hline & $\begin{array}{c}\text { Development } \\
\text { Office's Fees } \\
\text { and Assessments: } \\
\text { Fundraising } \\
\text { Subtotal }\end{array}$ & $\begin{array}{c}\text { Development } \\
\text { Office's Fees } \\
\text { and Assessments: } \\
\text { Nonfundraising } \\
\text { Subtotal }\end{array}$ & $\begin{array}{c}\text { Development } \\
\text { Office's Fees } \\
\text { and Assessments: } \\
\text { Total }\end{array}$ & $\begin{array}{r}\text { Development } \\
\text { Expenditures } \\
\text { by Campus } \\
\text { Units }\end{array}$ \\
\hline $1984-85$ & $1,198,847$ & & $1,198,847$ & 35,125 \\
$1985-86$ & $1,328,265$ & & $1,328,265$ & 62,400 \\
$1986-87$ & $1,424,659$ & & $1,424,659$ & 259,402 \\
$1987-88$ & $1,813,130$ & & $1,813,130$ & 461,960 \\
$1988-89$ & $2,422,106$ & $2,422,106$ & 623,783 \\
$1989-90$ & $1,849,729$ & & $2,676,969$ & 965,631 \\
$1990-91$ & $1,931,969$ & $2,629,946$ & $1,170,900$ \\
$1991-92$ & $1,848,278$ & 776,127 & $2,624,405$ & $1,305,208$ \\
$1992-93$ & $1,938,463$ & 847,444 & $2,785,907$ & $2,493,658$ \\
$1993-94$ & $2,037,739$ & $1,057,718$ & $3,095,457$ & $2,708,337$
\end{tabular}


is based on actual expenditures for most units and a conservative estimate (as discussed earlier) for the remaining units.

Although campus units were not very active with respect to campus development activities for the first several years in this study, activities increased quite dramatically during the late 1980s and early 1990s. For example, unit expenditures for development more than quadrupled from 1985-86 to 1986-87 and almost doubled from 1986-87 to 1987-88. Campus units' development expenditures doubled again within two years. Even following such rapid growth in the 1980s, school, or unit-level, development expenditures nearly tripled by the mid-1990s. Given that it is a newer campus and a public, research university facing declining state support (when adjusted for inflation and enrollments), it is not surprising that the academic units have increased their individual investments in fundraising. (See Grunig, 1995, for a discussion of the payoffs to decentralized versus centralized development programs.)

\section{Results}

Table 3 shows the traditional measures of fundraising efficiency: revenues raised per dollar spent and amount spent per dollar raised. This table gives the historical data about the opportunity costs of fundraising that are relevant to campus decision makers. It should be noted that there are two complete sets of calculations in this table. One set (the third and fourth columns) looks at the efficiency measures with respect to fundraising expenditures alone. This is comparable to the data used in CASE/NACUBO, except that it does

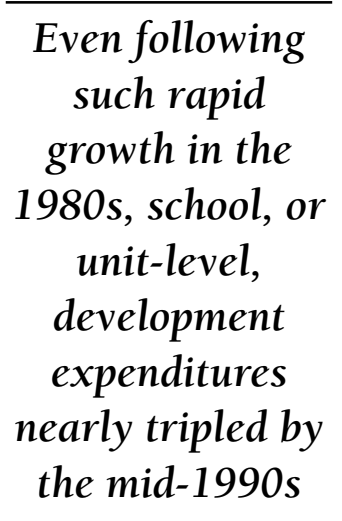

Table 3. Costs Versus Benefits of Fundraising

\begin{tabular}{|c|c|c|c|c|c|c|c|c|}
\hline Year & $\begin{array}{c}\text { Total } \\
\text { Fundraising } \\
\text { Costs } \\
\text { (Excludes } \\
\text { 40-47.5\% of } \\
\text { mgmt. fees) } \\
\text { Nominal \$ }\end{array}$ & $\begin{array}{c}\text { Total } \\
\text { Fundraising } \\
\text { Costs } \\
\text { Real } 1993 \$\end{array}$ & $\begin{array}{c}\text { Rev's. } \\
\text { per \$ } \\
\text { Spent } \\
\text { Real } \\
1993 \$\end{array}$ & $\begin{array}{l}\text { Amount } \\
\text { Spent } \\
\text { per \$ } \\
\text { Raised }\end{array}$ & $\begin{array}{l}\text { Total Costs } \\
\text { (Includes } \\
\text { admin. and } \\
\text { gross mgmt. } \\
\text { fees) } \\
\text { Nominal \$ }\end{array}$ & $\begin{array}{l}\text { Total Costs } \\
\text { (Includes } \\
\text { admin. and } \\
\text { gross mgmt. } \\
\text { fees) } \\
\text { Real } 1993 \$\end{array}$ & $\begin{array}{l}\text { Gross } \\
\text { Rev's. } \\
\text { per \$ } \\
\text { Spent } \\
\text { Real } \\
1993 \$\end{array}$ & $\begin{array}{c}\text { Gross } \\
\text { Amount } \\
\text { Spent } \\
\text { per \$ } \\
\text { Raised }\end{array}$ \\
\hline $1984-85$ & $1,233,972$ & $1,716,159$ & 3.2 & 0.32 & $1,233,972$ & $1,716,159$ & 3.2 & 0.32 \\
\hline 1985-86 & $1,390,665$ & $1,867,575$ & 4.8 & 0.21 & $1,390,665$ & $1,867,575$ & 4.8 & 0.21 \\
\hline 1986-87 & $1,684,061$ & $2,220,317$ & 5.9 & 0.17 & $1,684,061$ & $2,220,317$ & 5.9 & 0.17 \\
\hline 1987-88 & $2,275,090$ & $2,893,930$ & 3.9 & 0.26 & $2,275,090$ & $2,893,930$ & 3.9 & 0.26 \\
\hline 1988-89 & $3,045,889$ & $3,720,465$ & 5.3 & 0.19 & $3,045,889$ & $3,720,465$ & 5.3 & 0.19 \\
\hline 1989-90 & $2,815,360$ & $3,280,802$ & 3.4 & 0.29 & $3,642,601$ & $4,244,805$ & 2.6 & 0.38 \\
\hline 1990-91 & $3,102,868$ & $3,430,486$ & 3.1 & 0.33 & $3,800,845$ & $4,202,159$ & 2.5 & 0.40 \\
\hline 1991-92 & $3,153,486$ & $3,345,659$ & 3.2 & 0.32 & $3,929,613$ & $4,169,083$ & 2.5 & 0.39 \\
\hline 1992-93 & $4,432,121$ & $4,564,801$ & 2.4 & 0.41 & $5,279,565$ & $5,437,614$ & 2.1 & 0.49 \\
\hline 1993-94 & $4,746,076$ & $4,746,076$ & 2.6 & 0.39 & $5,803,794$ & $5,803,794$ & 2.1 & 0.47 \\
\hline 1994-95 & $4,905,490$ & $4,776,572$ & 2.9 & 0.35 & $5,975,256$ & $5,818,225$ & 2.4 & 0.42 \\
\hline
\end{tabular}




These ratios give
us an indication
of the order of
magnitude by
which the
currently
accepted
standards
promulgated by
CASE/NACUBO
misrepresent the
true costs of
operating a
development
program

not include the private (nongovernmental) grants that CASE/ NACUBO include. The second set of efficiency measures are in the seventh and eighth columns and refer to the "full costs" associated with fundraising. Full costs are the traditional costs of fundraising per-ask plus administrative and asset management costs of operating a development office. Recall that there would not be significant administrative and asset management costs in a development program if there were not fundraising costs and efforts. As discussed earlier, there may be additional or better measurements that might assess the asset management and endowment administration costs against the value of the endowment or the value of private gifts.

As noted earlier, although this analysis captures many more of the actual costs than prior analyses, the reference to "full costs" in the results section of this article is somewhat misleading as the analysis does not include any campus fees for space utilization, depreciation, maintenance, utilities, and so on, for the development offices that are distributed across the campus. However, it does capture these costs for the main development offices. Likewise, per CASE/NACUBO (1990), it also excludes the pro rata share of the time of the university president, campus chancellor, and deans. While this is consistent with other analyses, it significantly understates the true costs. Gathering these data would require a great deal of time on the part of the offices of the president, the chancellor, and each of the deans. (If using these data became the norm, then these offices would establish systems to capture the data; however, to do so exclusively for this analysis would have been burdensome.) Also, as already stated, it does not include the costs for alumni relations, public relations, and so on, some or all of which might be viewed as expenditures in support of development or which might be areas into which development expenditures are shifted.

The results as shown in Table 3 indicate that including the administrative and asset management costs (at least those that can be tracked) increased the total costs of raising a dollar from $\$ 0.35$ to $\$ 0.42$ in $1994-95$, a 20 percent increase. Similarly, including administrative and asset management costs raises the three-year average cost of fundraising from $\$ 0.38$ to $\$ 0.46$ for each dollar raised (a 21 percent increase). Obviously, these ratios would increase if there were additions for the pro rata time of the university president, campus chancellor, and deans; for the opportunity cost of the space, utilities, and so on; or for the alumni relations, public relations, or other costs "in support of development." However, these ratios give us an indication of the order of magnitude by which the currently accepted standards promulgated by CASE/NACUBO misrepresent the true costs of operating a development program.

Table 4 includes the private grants that the Council for the Aid to Education (CAE) uses in its reports. These data are shown to allow comparability to the CAE data and to illustrate how fallacious 


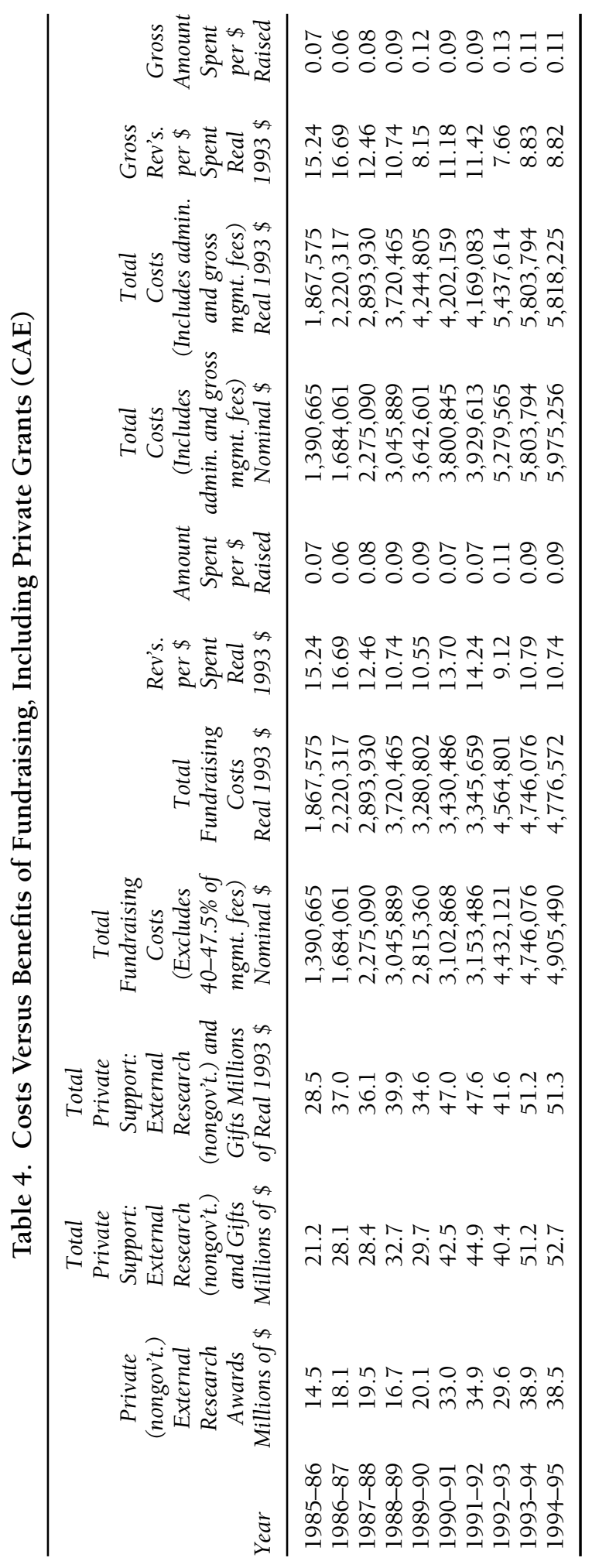


this measurement is. For example, the 1994-95 data excluding grants indicates that $\$ 0.35$ was spent per dollar raised (see Table 3 ). (It averaged $\$ 0.38$ for the past three years.) On the other hand, incorporating the nongovernmental grants lowers this ratio to $\$ 0.09$ (or an average of $\$ 0.10$ for the past three years). Excluding the private grants raises the estimated cost of fundraising virtually by a factor of four but provides a much more meaningful insight into actual development costs and benefits.

The data in Table 4 are the most comparable to other nationally reported data. These results suggest that when one includes the significant private grant support and excludes the "full costs," the cost of fundraising at this campus is quite reasonable relative to other programs. For example, the fifty-one programs participating in the CASE/NACUBO (1990) study from colleges and universities across the nation reported a median cost of development of $\$ 0.11$ per dollar raised. The range for the middle 50 percent of participating institutions was $\$ 0.08$ to $\$ 0.16$. Similarly, Richard Ramsden (1979) reports an average of $\$ 0.07$ for fourteen private universities and $\$ 0.10$ for eleven private colleges. These institutions were all part of the Consortium on Financing Higher Education (COFHE). This places the cost of fundraising at this campus just at the national average in the CASE/NACUBO study (1990) and 29 percent above the average of the fourteen private universities in the Ramsden (1979) study. However, we would expect that the fundraising costs at a large, public, research university located in an urban setting would be greater than that of a group of selective private universities.

\section{A New Methodology}

Table 5 replicates Tables 3 and 4, but it also includes estimates for changes in pledges and changes in bequest expectancies. Table 5 reports data only for 1994-95; the development office did not maintain records for changes in pledges or changes in bequest expectancies broken down by campus in previous years. Like the preceding tables, Table 5 includes analyses of costs and benefits that examine fundraising costs alone (the third and fourth columns) and those that include administrative and asset management fees (the sixth and seventh columns). As already mentioned, the cost of fundraising (alone) per dollar of gift income at the campus in 1994-95 was $\$ 0.35$. Adding the changes in pledges and changes in bequest expectancies at present value lowers the cost per dollar of gift income to $\$ 0.27$, or $\$ 0.22$ if one uses the face value estimate. Finally, including the private (nongovernmental) grants and changes in pledges and in the present value of bequest expectancies lowers the ratio further to $\$ 0.09$ expended per dollar raised.

If one includes the asset management and administrative expenses of the development office, the ratio of costs per dollar raised is $\$ 0.42$ for $1994-95$, using our most simple measure (private 


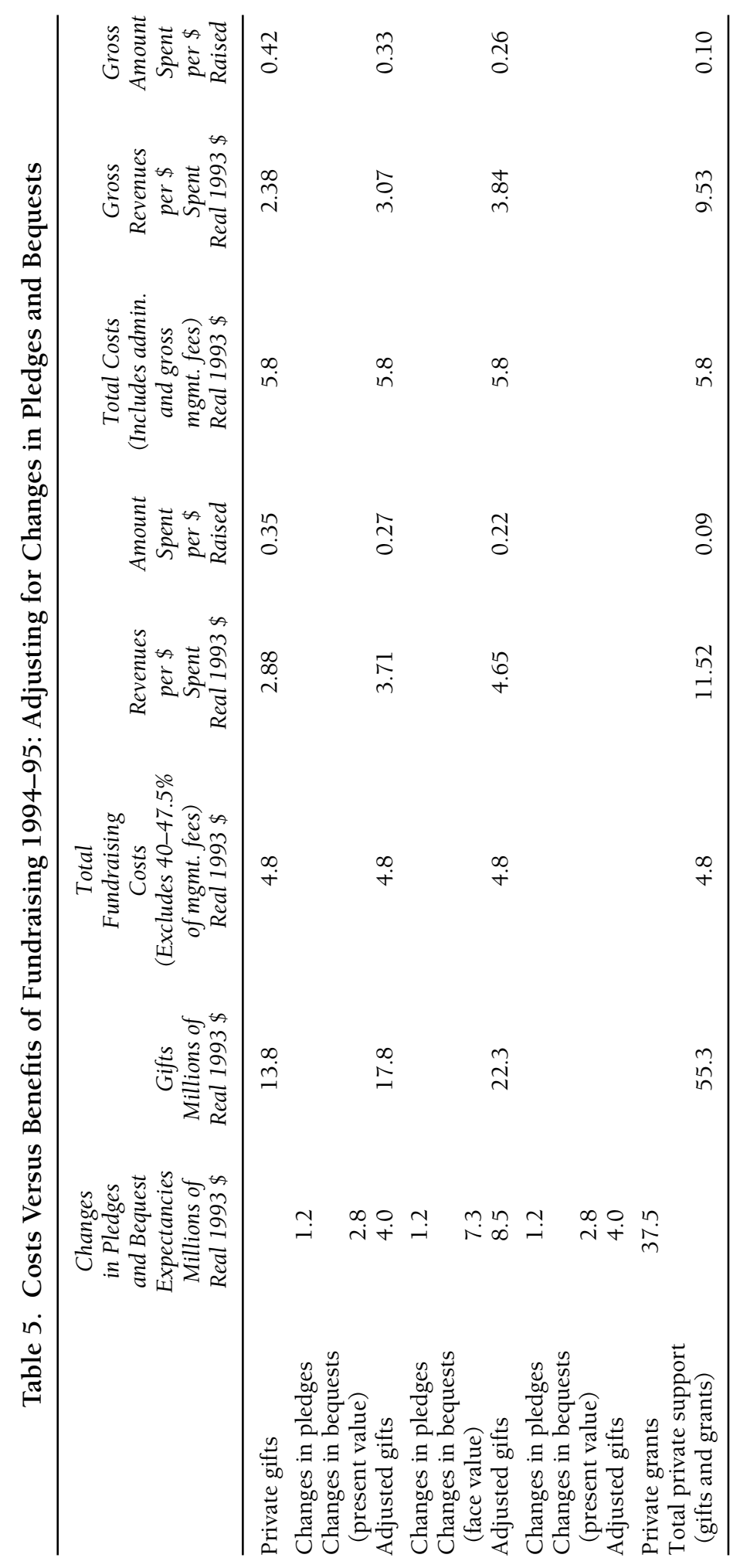




\begin{tabular}{c}
\hline From an \\
economic \\
perspective, \\
clearly it is much \\
more accurate to \\
value the bequest \\
expectancies \\
using a \\
discounted \\
present valuation
\end{tabular}

gifts only). Adding changes in pledges and in the present value of bequest expectancies drops the cost-benefit ratio to $\$ 0.33$, and using the face value of changes in bequest expectancies lowers it further to $\$ 0.26$. Adding private grants to changes in pledges and in the present value of bequest expectancies drops the cost-benefit ratio to $\$ 0.10$.

The group of university financial officers decided to report the changes in bequest expectancies at both the face value (what economists would call the "future value") and at the (discounted) present value. As can be seen in Table 5, such differences can be large. The face value of changes in bequest expectancies is $\$ 7.3$ million, whereas the present value is $\$ 2.8$ million. The difference stems from the fact that the face value shows how much the bequest is for at some future date. However, recognizing that a dollar is worth more today than in the future, the present value shows how much one would be willing to receive today to be just as well off as the face value at some specified point in the future. (Per CASE, 1994, the discount rate is the applicable federal rate, which approximates 120 percent of the thirty-year Treasury note.) From an economic perspective, clearly it is much more accurate to value the bequest expectancies using a discounted present valuation. (Note that bequests are not recognized on the books until they come in because donors can change their wills.)

\section{Implications}

Per Steinberg (1994), efficiency considerations require that internal decisions be made on the basis of continuing to invest in fundraising up to the point that the marginal costs are equal to the marginal benefits. Ideally, this would be done in the manner recommended by Greenfield (1996) such that the investment in each of the various fundraising strategies would continue up to the point at which the marginal costs of each approach equaled the marginal benefits derived from that approach. Nonetheless, practitioners can expect that external boards, donors, and other constituencies will continue to place significant emphasis on average costs and average benefits in the form of cost-benefit analyses. It is inevitable that even when boards understand the maximizing concepts, they will still want the organization to demonstrate that it is among the "best" in its field by maintaining a relatively low cost-benefit ratio. More important, even if boards and other constituencies understand and endorse the move to a marginal analysis, they will still make inferior decisions if they are given inferior data.

This article has focused on the methodological changes necessary to improve both internal decision-making and external benchmarking and accountability practices. The erroneous inclusion of all private (nongovernmental) grants affects both the marginal analysis (by overstating the marginal benefits) and the cost-benefit analysis (by exaggerating the total benefits). Similarly, the exclusion of 
several significant costs of fundraising (such as the pro rata share of the time of the president and other senior academic officers, costs associated with space utilization, and other costs that are in support of fundraising) understates the true marginal cost of fundraising, as well as the true average cost. In addition, this article recommends including the changes in pledges and changes in bequest expectancies to more accurately correlate the time periods of effort and dollars invested in fundraising with the realization of the returns on that investment. This change would affect both the marginal benefits of fundraising and the average benefits.

The bottom line for practitioners is that nobody wants to be the first (or the only) one to be honest about the true costs and benefits of fundraising because the public has been misled for so long. The public has been convinced that in many organizations, it only takes a few cents (a dime is commonly reported) to raise a dollar. Hence, the belief that it should only take a few cents to raise a dollar becomes normative. The first practitioners to reveal a reality that differs from this fantasy may be fired (thus the Greenfield quotation at the beginning of the article).

It would be far better for organizations that rely on fundraising to embrace these changes more broadly and collaboratively as industry-wide best practices and report the corresponding benchmark data. Rob Paton (forthcoming) discusses some of the positive and negative experiences that a group of charitable organizations in the United Kingdom have had in sharing these types of data over the past decade. It will require considerable effort to educate boards and other constituencies, but doing so will place the discussion in a more manageable context. As opposed to the status quo, in which the industry norms lead to very biased, inconsistent, and misleading results, implementation of these changes on an industry-wide basis will yield better internal decision making and external accountability without unnecessarily threatening the jobs of the senior management teams.

Patrick Michael Rooney is special assistant to the chancellor, associate professor of economics, and adjunct associate professor of philanthropic studies at Indiana University Purdue University (IUPU)-Indianapolis, and assistant dean at IUPU-Columbus.

\section{References}

CASE (Council for Advancement and Support of Education). "Management and Reporting Standards for Educational FundRaising Campaigns." Unpublished working paper, Apr. 18, 1994, draft.

CASE (Council for Advancement and Support of Education). "FundRaising Activities Reporting Standards: Standards for Annual
The bottom line for practitioners is that nobody wants to be the first (or the only) one to be honest about the true costs and benefits of fundraising 
Giving and Campaign Fund Raising." Unpublished working paper, Nov. 8, 1996, draft.

CASE/NACUBO (Council for Advancement and Support of Education and the National Association of College and University Business Officers). Expenditures in Fund Raising, Alumni Relations, and Other Constituent (Public) Relations. Washington, D.C.: Council for Advancement and Support of Education, 1990.

Greenfield, J. Fund-Raising Cost Effectiveness: A Self-Assessment Workbook. New York: Wiley, 1996.

Grunig, S. "The Impact of Development Office Structure on FundRaising Efficiency for Research and Doctoral Institutions." Journal of Higher Education, 1995, 66 (6), 686-699.

Heeman, W. "Editor's Notes." In W. Heeman (ed.), Analyzing the Cost Effectiveness of Fund Raising. New Directions for Institutional Advancement, no. 3. San Francisco: Jossey-Bass, 1979.

Leslie, J. "Variations in Fund Raising Potential Among Colleges and Universities." In W. Heeman (ed.), Analyzing the Cost Effectiveness of Fund Raising. New Directions for Institutional Advancement, no. 3. San Francisco: Jossey-Bass, 1979.

Lindahl, W. "Multiyear Evaluation of Fundraising Performance." In J. M. Greenfield (ed.), Financial Practices for Effective Fundraising. New Directions for Philanthropic Fundraising, no. 3. San Francisco: Jossey-Bass, 1994.

Paton, R. "Performance Comparisons in Fundraising: The Case of Fundratios." International Journal of Nonprofit and Voluntary Sector Marketing, forthcoming.

Ramsden, R. "The COFHE Development Study: Insights and Implications." In W. Heeman (ed.), Analyzing the Cost Effectiveness of Fund Raising. New Directions for Institutional Advancement, no. 3. San Francisco: Jossey-Bass, 1979.

Rooney, P. M. "Enhanced Accountability: Measuring Costs and Benefits of Fund Raising." Paper presented at the 27th Annual ARNOVA Conference, Seattle, Nov. 1998.

Rooney, P. M. "Fund Raising Efficiency vs. Effectiveness: Is There a Difference?" Unpublished manuscript, 1999.

Steinberg, R. "Economics and Philanthropy: A Marriage of Necessity for Nonprofit Organizations." In J. M. Greenfield (ed.), Financial Practices for Effective Fundraising. New Directions for Philanthropic Fundraising, no. 3. San Francisco: Jossey-Bass, 1994.

Teitelbaum, R. "How to Find Out What It's Really Costing You to Operate All Those Fund-Raising Programs." In W. Heeman (ed.), Analyzing the Cost Effectiveness of Fund Raising. New Directions for Institutional Advancement, no. 3. San Francisco: Jossey-Bass, 1979. 